\title{
Incomplete duplication of a lower extremity (polymelia): a case report
}

Nelson Montalvo ${ }^{1 *}$, Ligia Redrobán ${ }^{1}$ and Victor Hugo Espín ${ }^{2}$

\begin{abstract}
Introduction: Polymelia, or congenital duplication of a limb, is an extremely rare entity in humans, with few cases reported in the literature.

Case presentation: We present the case of a six-month-old Hispanic boy born with a lower limb bud on the left posterior thigh.

Conclusion: The infant had a favorable outcome and evolution after surgical treatment of his supernumerary limb, with no after-effects or impairment whatsoever.
\end{abstract}

\section{Introduction}

Polymelia (supernumerary limbs) is an extremely uncommon congenital entity rarely reported in humans [1,2], though it is frequently reported in animals [3-5]. Its pathogenesis is heterogeneous and includes incomplete separation of monozygotic twins [6-8].

\section{Case presentation}

Our case report concerns a six-month-old Hispanic firstborn son of young, nonconsanguineous parents with no family history of hereditary diseases or major dysmorphology. The pregnancy passed without major complications and with no accidental or work-related exposure to genotoxic agents.

The infant was born at term with normal anthropometry and no complications or major dysmorphic features except a limb bud, which was located on the posterointernal face of the left thigh (Figure 1).

The undeveloped limb was surgically removed, and the 11-cm-long specimen was sent to the Pathology Service. The surgically removed end was bloody and had an exposed bone segment. There were three digitiform formations at the opposite end, two of which were joined together in a tweezer-like configuration. A kink with limited movement and covered with skin and abundant adipose tussue was observed in the central part (Figure 2).

\footnotetext{
* Correspondence: nmontalvof@gmail.com

${ }^{1}$ Pathology Service, Hospital Metropolitano, Av Mariana de Jesús s/n y Nicolás Arteta, Quito, Ecuador

Full list of author information is available at the end of the article
}

The surgical specimen was formalin fixed and paraffin embedded, cut at $4 \mu \mathrm{m}$ and subsequently stained with hematoxylin and eosin.

The histopathological diagnosis was incomplete congenital duplication of the left lower extremity (polymelia). Histological analysis revealed diaphyseal endochondral ossification and cartilaginous epiphyseal plates maturing in accordance with the infant's age (Figures 3, 4 and 5).

\section{Discussion}

Polymelia (supernumerary limbs) is a rare congenital entity scarcely reported in humans, though not uncommonly in animals [1-4,9-12].

Limb development involves a very large number of genes [13]. One gene widely associated with the development of supernumerary limbs is the mouse mutant disorganization Ds gene [OMIM:223200] [9,14], which is a semidominant gene with variable penetrance in heterozygotes and lethality in homozygotes; $67 \%$ of heterozygotes have multiple defects and the rest have single defects, in which polymelia is prominent [10].

Limb development is a very complex process involving precise gene regulation fundamental to normal growth [11]. Findings in animal models have explained a great deal about these functions and have improved our understanding of the etiopathogeny of malformations, but more research is necessary to extend knowledge of these delicate processes. Surgical resection of the accessory limb at an early age is recommended in patients with supernumerary extremities $[12,15]$. 


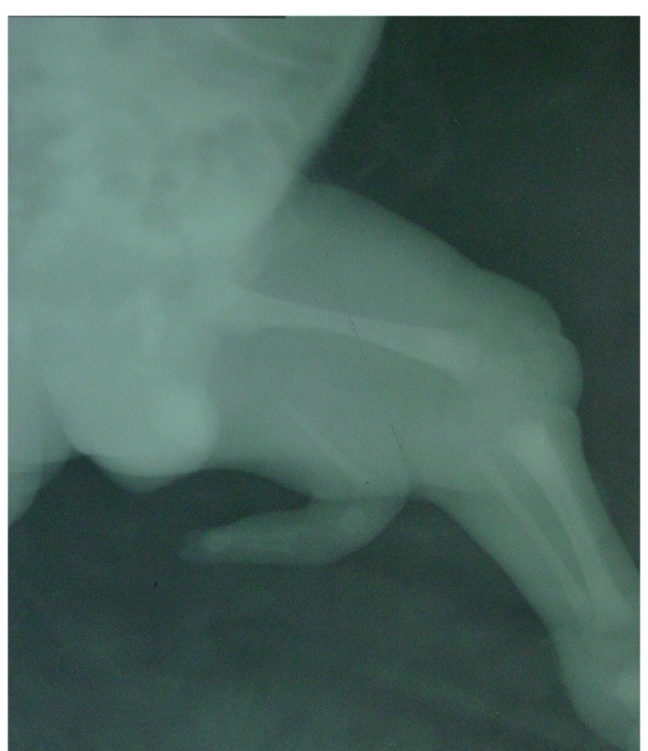

Figure 1 Plain film radiograph of left lower extremity shows an accessory lower limb bud on the posterior face.

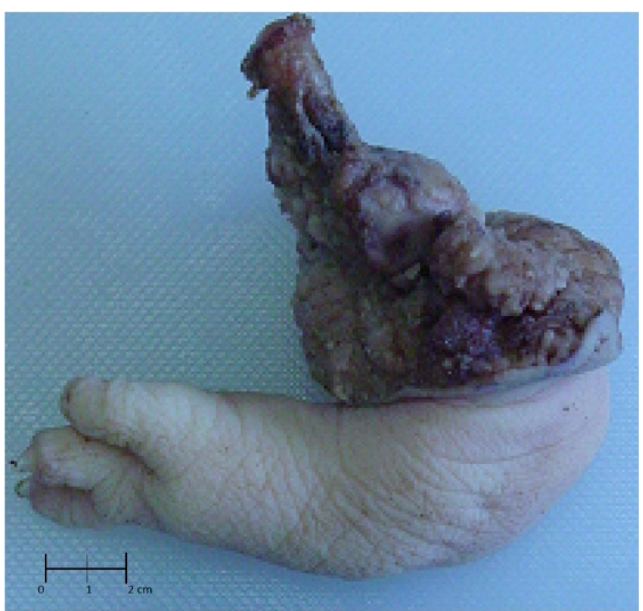

Figure 2 Photograph of supernumerary limb with exposed bone segment. Three digitiform formations are visible at the opposite end

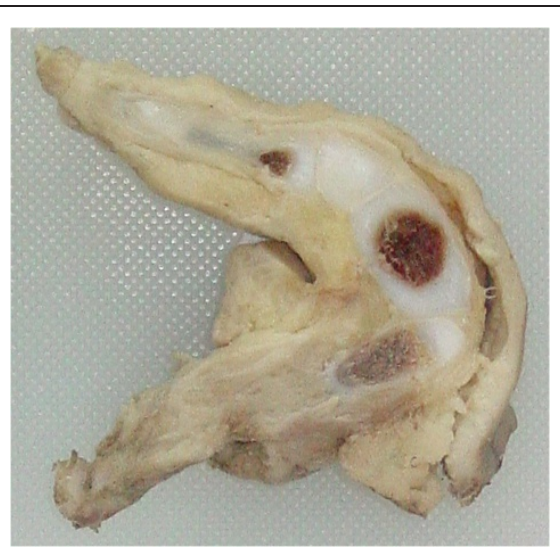

Figure 3 Photograph of the limb bud cut along its long axis showing islands of cartilage and centers of ossification surrounded by subcutaneous cellular tissue and skin.

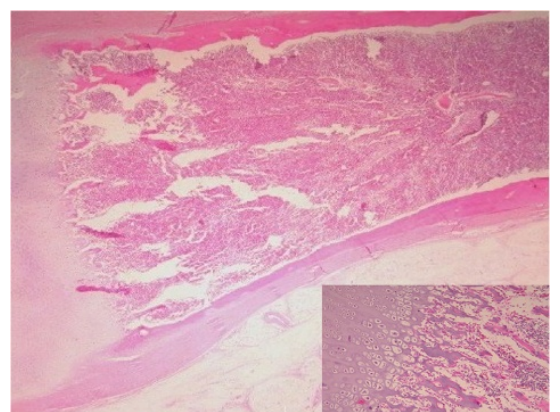

Figure 4 Histological specimen showing endochondral ossification in the diaphysis and the epiphysis (inset, 20x).

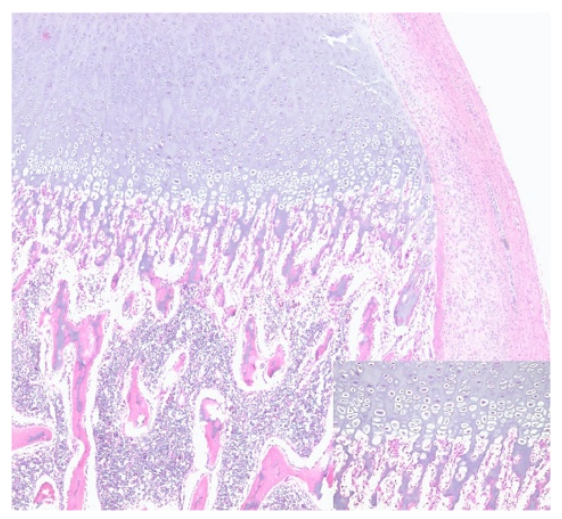

Figure 5 Histological analysis of supernumerary limb showing maturation of the cartilaginous growth plate in accordance with the infant's age (inset, $40 \times$ ). 


\section{Conclusion}

In our present case, the infant had a favorable outcome and evolution subsequent to surgical treatment of his supernumerary limb, with no sequelae or disability whatsoever to date.

\section{Consent}

Written informed consent was obtained from the patient's legal guardian(s) for publication of this case report and any accompanying images. A copy of the written consent is available for review by the Editor-in-Chief of this journal.

\section{Competing interests}

The authors declare that they have no competing interests.

\section{Authors' contributions}

NM performed the histological examination and diagnosis of the patient. LR and VE conducted a thorough literature review of duplication of the limbs in the human tract and were the major contributors to the writing of the manuscript. All authors read and approved the final manuscript.

\section{Acknowledgement}

The authors thank Cesar Vaca (technologist) for his valuable technical support.

\section{Author details}

'Pathology Service, Hospital Metropolitano, Av Mariana de Jesús s/n y Nicolás Arteta, Quito, Ecuador. ${ }^{2}$ Genetics Service, Hospital Carlos Andrade Marín, Av 18 de Septiembre y Ayacucho, Quito, Ecuador.

Received: 30 July 2013 Accepted: 24 February 2014

Published: 12 June 2014

\section{References}

1. Bannykh Sl, Bannykh Gl, Mannino FL, Jones KL, Hansen L, Benirschke K, Masliah E: Partial caudal duplication in a newborn associated with meningomyelocele and complex heart anomaly. Teratology 2001, 63:94-99.

2. Gómez Dumm C: Skeletal system and limbs in human embryology. In Human Embryology: Atlas and Text [in Spanish]. Buenos Aires, Argentina: El Ateneo; 2003:198-200.

3. Brook WJ, Díaz-Benjumea FJ, Cohen SM: Organizing spatial pattern in limb development. Annu Rev Cell Dev Biol 1996, 12:161-180.

4. Langman J: Skeletal system. In Medical Embryology. 4th edition. Edited by Sadler TW. Baltimore: Williams \& Wilkins; 1982:129-143.

5. Moore KL, Persaud TVN: Skeletal system in the developing human. In The Developing Human: Clinically Oriented Embryology. 7th edition. Philadelphia, PA: Saunders; 2003:405-422.

6. Cohn MJ, Izpisúa-Belmonte JC, Abud H, Heath JK, Tickle C: Fibroblast growth factors induce additional limb development from the flank of chick embryos. Cell 1995, 80:739-746.

7. Crossley PH, Minowada G, MacArthur CA, Martin GR: Roles for FGF8 in the induction, initiation, and maintenance of chick limb development. Cell 1996, 84:127-136.

8. Ohuchi H, Nakagawa T, Yamamoto A, Araga A, Ohata T, Ishimaru Y, Yoshioka H, Kuwana T, Nohno T, Yamasaki M, Itoh N, Noji S: The mesenchymal factor, FGF10, initiates and maintains the outgrowth of the chick limb bud through interaction with FGF8, an apical ectodermal factor. Development 1997, 124:2235-2244.

9. Winter RM, Donnai D: A possible human homologue for the mouse mutant disorganisation. J Med Genet 1989, 26:417-420.

10. Norman WH: A child with three lower extremities. J Bone Joint Surg Am 1964, 46:1755-1758.

11. Hanley EN Jr, Stanitski CL: Incomplete congenital duplication of a lower extremity: a case report. J Bone Joint Surg Am 1980, 62:479-481.

12. Acharya S, Pradhan NK, Rao PT: Congenital incomplete reduplication of the lower limb: a case report. Int Orthop 1993, 17:308-309.
13. Vogel A, Rodriguez C, Izpisúa-Belmonte JC: Involvement of FGF-8 in initiation outgrowth and patterning of the vertebrate limb. Development 1996, 122:1737-1750.

14. Cohn MJ, Patel K, Krumlauf R, Wilkinson DG, Clarke JD, Tickle C: Hox9 genes and vertebrate limb specification. Nature 1997, 387:97-101.

15. García-Espinosa I, García-Cruz R, Huerta-Mendoza H, Cabrera-Hernández R, Merelo-Villafán I, López-Alfonso A: [Polymelia: case report and review of the literature] [in Spanish]. Acta Ortop Mex 2002, 16:272-275.

doi:10.1186/1752-1947-8-184

Cite this article as: Montalvo et al.: Incomplete duplication of a lower extremity (polymelia): a case report. Journal of Medical Case Reports 2014 8:184.

\section{Submit your next manuscript to BioMed Central and take full advantage of:}

- Convenient online submission

- Thorough peer review

- No space constraints or color figure charges

- Immediate publication on acceptance

- Inclusion in PubMed, CAS, Scopus and Google Scholar

- Research which is freely available for redistribution 